\title{
Towards Dual-Metal Catalyzed Hydroalkoxylation of Alkynes
}

\author{
Oscar F. González-Belman ${ }^{1,2}$, Artur Brotons-Rufes ${ }^{1}$, Michele Tomasini ${ }^{1,3}$ (D) Laura Falivene $^{3}$ (D), Lucia Caporaso ${ }^{3}$, \\ Jose Oscar C. Jiménez-Halla ${ }^{2}$ and Albert Poater ${ }^{1, * \mathbb{D}}$ \\ 1 Institut de Química Computacional i Catàlisi, Departament de Química, Universitat de Girona, \\ c/Ma Aurèlia Capmany 69, 17003 Girona, Catalonia, Spain; ofgb15@gmail.com (O.F.G.-B.); \\ arturbr04@gmail.com (A.B.-R.); michele.tomasini3@studio.unibo.it (M.T.) \\ 2 Departamento de Química, Universidad de Guanajuato, Noria Alta S/N, Guanajuato 36050, Mexico; \\ jjimenez@ugto.mx \\ 3 Department of Chemistry, University of Salerno, Via Ponte Don Melillo, 84084 Fisciano, Italy; \\ lafalivene@unisa.it (L.F.); lcaporaso@unisa.it (L.C.) \\ * Correspondence: albert.poater@udg.edu; Tel.: +34-972419403
}

Citation: González-Belman, O.F.; Brotons-Rufes, A.; Tomasini, M.; Falivene, L.; Caporaso, L.; JiménezHalla, J.O.C.; Poater, A. Towards Dual-Metal Catalyzed Hydroalkoxylation of Alkynes. Catalysts 2021, 11, 704. https:// doi.org/10.3390/catal11060704

Academic Editor: Hiroto Yoshida

Received: 11 May 2021

Accepted: 29 May 2021

Published: 2 June 2021

Publisher's Note: MDPI stays neutral with regard to jurisdictional claims in published maps and institutional affiliations.

Copyright: (c) 2021 by the authors. Licensee MDPI, Basel, Switzerland. This article is an open access article distributed under the terms and conditions of the Creative Commons Attribution (CC BY) license (https:// creativecommons.org/licenses/by/ $4.0 /)$.

\begin{abstract}
Poly (vinyl ethers) are compounds with great value in the coating industry due to exhibiting properties such as high viscosity, soft adhesiveness, resistance to saponification and solubility in water and organic solvents. However, the main challenge in this field is the synthesis of vinyl ether monomers that can be synthetized by methodologies such as vinyl transfer, reduction of vinyl phosphate ether, isomerization, hydrogenation of acetylenic ethers, elimination, addition of alcohols to alkyne species etc. Nevertheless, the most successful strategy to access to vinyl ether derivatives is the addition of alcohols to alkynes catalyzed by transition metals such as molybdenum, tungsten, ruthenium, palladium, platinum, gold, silver, iridium and rhodium, where gold-NHC catalysts have shown the best results in vinyl ether synthesis. Recently, the hydrophenoxylation reaction was found to proceed through a digold-assisted process where the species that determine the rate of the reaction are $\mathrm{PhO}-[\mathrm{Au}(\mathrm{IPr})]$ and alkyne-[Au(IPr)]. Later, the improvement of the hydrophenoxylation reaction by using a mixed combination of $\mathrm{Cu}-\mathrm{NHC}$ and $\mathrm{Au}-\mathrm{NHC}$ catalysts was also reported. DFT studies confirmed a cost-effective method for the hydrophenoxylation reaction and located the rate-determining step, which turned out to be quite sensitive to the sterical hindrance due to the NHC ligands.
\end{abstract}

Keywords: hydrophenoxylation; gold; copper; dual catalysis; C-O bond formation

\section{Introduction}

Over time, alchemists and chemists have directed their efforts to control chemical processes through "species capable of accelerating the rate of reaction." However, since the 18th century, they have made significant advances in the catalysis field. Some contributions, such as sulfuric acid production, the conversion of starch to sugar proposed by Kirchoff, the first safety lamp for coal miners and the catalyst definition by Berzelius, marked the beginning of this field [1]. Sometime after, in the early 19th century, Paul Sabatier reported the hydrogenation of unsaturated organic compounds catalyzed by nickel [2], which marked the birth of modern catalysis. At the same time, the oil industry began to exploit the goodness of catalysis in processes such as the catalytic cracking by the pioneer Eugene Houndry in 1922 [3] and hydrocracking [4]. The evolution of the petrochemical industry during the first half of the 19th century led to the birth of the polymer field.

The new business of the chemical industry had been born with the catalytic synthesis of building blocks of polymers such as acrylonitrile [5] and vinyl chloride monomer [6]. Moreover, since the 1920s, the Du Pont company has positioned itself at the top of the polymer market with its polymeric films and synthetic fibers such as cellophane, rayon, nylon and polyester [7]. Due to properties such as high viscosity, soft adhesiveness, 
resistance to saponification and solubility in water and organic solvents, poly(vinyl ethers) have been the focus of the polymer industry [8].

\section{Synthesis of Vinyl Ethers}

\subsection{Alcohols to Get Vinyl Ethers}

Chemists around the world have focused their efforts to improve the synthetic strategies for obtaining vinyl ether monomers. Nevertheless, vinyl ethers can be synthesized by vinyl trans-etherification catalyzed by compounds such as $[\operatorname{Ir}(\mathrm{cod}) \mathrm{Cl}]_{2}$ (Equation (1)) [9], $\mathrm{Pd}(\mathrm{OAc})_{2}$ (Equation (2)) [10] and $\mathrm{AuClPPh}_{3}$ (Equation (3)) [11], where gold catalysis has shown the best effectivity for the vinylation of carboxylic acids.
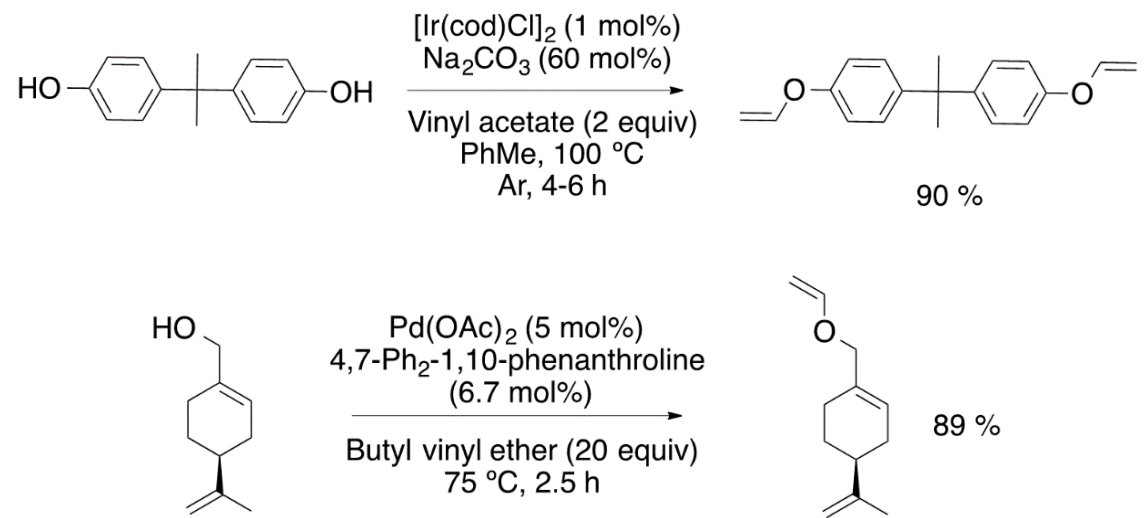

$\mathrm{Pd}(\mathrm{OAc})_{2}(5 \mathrm{~mol} \%)$ 4,7- $\mathrm{Ph}_{2}-1,10$-phenanthroline (6.7 mol\%)

Butyl vinyl ether (20 equiv) $75^{\circ} \mathrm{C}, 2.5 \mathrm{~h}$
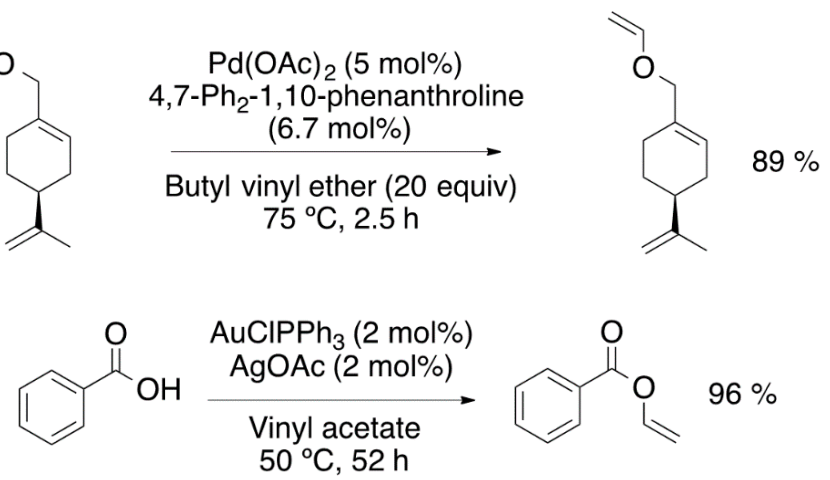

\subsection{Reduction of Vinyl Phosphate Ether}

Other precursors of vinyl ethers are vinyl phosphate ethers. However, to obtain the desired vinyl compound, the phosphate group can be removed by dissolving it with a metal solution. A clear example for the reductive cleavage of the C-P bond is the Birch methodology for the synthesis of chiral vinyl ethers (Equation (4)) [12].

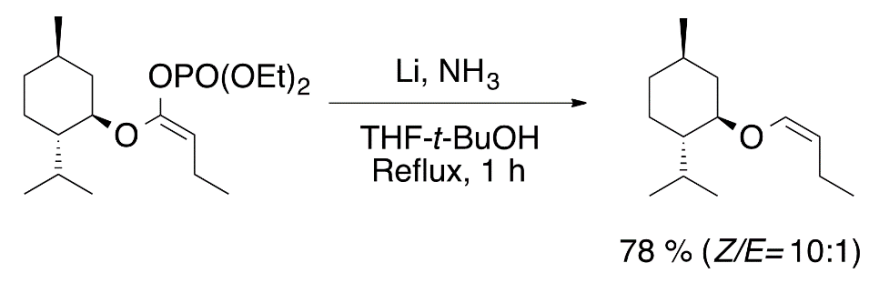

\subsection{Isomerization of Allyl Ethers to Vinyl Ethers}

Allyl ethers tend to isomerize to vinyl ethers in the presence of a strong base, such as potassium tert-butoxide [13]. However, transition metal species can achieve the isomeriza- 
tion of allyl ether substrates. Catalysts such as $(\mathrm{PPh})_{3} \mathrm{RhCl}$ (Equation (5)) [14] and $\mathrm{Fe}(\mathrm{CO})_{5}$ (Equation (6)) have shown good catalytic activity [15].
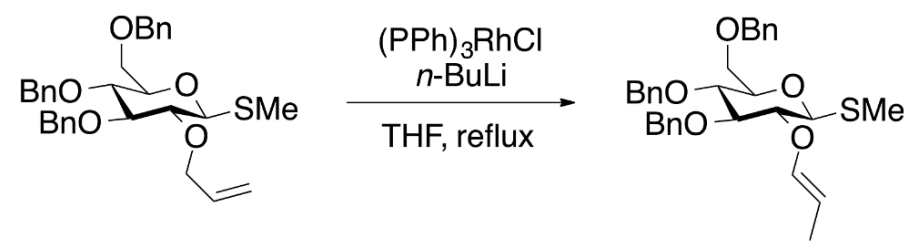

$95 \%(E / Z=2.7: 1)$

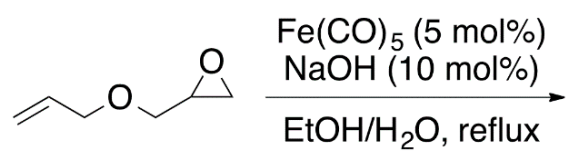

$87 \%(E / Z=49: 51)$

\subsection{Hydrogenation of Acetylenic Ethers}

Hydrogen addition to $\pi$-bonds in acetylenic ethers is another synthetic strategy to obtain vinyl ethers. Some transition metals, such as palladium, can achieve the hydrogenation of the unsaturated carbons (Equation (7)) [16].

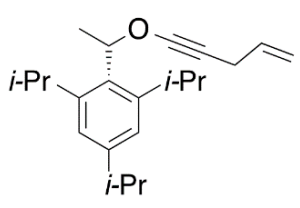

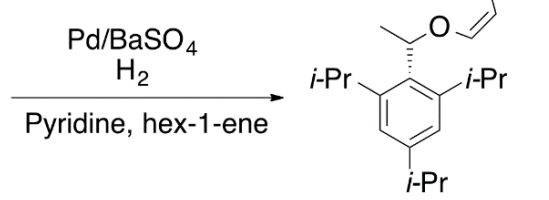

\subsection{Elimination}

Ethers containing $\alpha$ or $\beta$ leaving groups, such as halogens [17], hydroxyl [18], alkoxide [19] and silyl oxide [20], can undergo the elimination reaction in the presence of a strong base (Scheme 1).

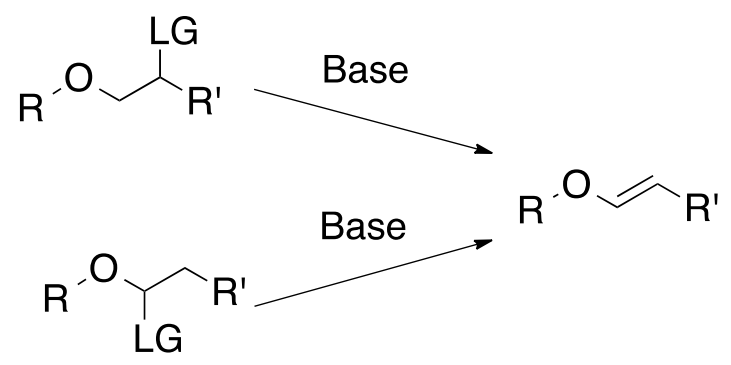

\section{$\mathrm{LG}=$ Halogens, $\mathrm{OH}, \mathrm{OR}$ or O-SiR}

Scheme 1. Synthesis of vinyl ethers via elimination.

\subsection{Olefination of Carbonyl Compounds}

Another way to access vinyl ether is through carbonyl compounds. In these compounds, the carbon-oxygen double bond, i.e., a carbonyl group, can be shifted into a carbon-carbon double bond by the Wittig reaction [21] or Julia olefination [22]. Carbonyl 
compounds, such as lactones (Equation (8)) [23] and ketones (Equation (9)) [24], can be converted into vinyl ethers in the presence of phosphoranes.<smiles>O=C1OCc2ccccc21</smiles>

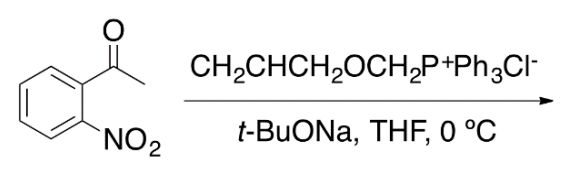<smiles>CCOC(=O)C=Cc1ccccc1</smiles><smiles>CCOC(=O)/C=C1\OCc2ccccc21</smiles>

$89 \%(E / Z=15: 85)$<smiles>C=CCO/C=C(\C)c1ccccc1[N+](=O)[O-]</smiles>

$65 \%$

Julia olefination and its variants have become a versatile synthetic tool for the synthesis of vinyl ethers. However, Berthelette has reported an efficient olefination process for aldehydes and ketones by using alkoxysulfone anions (Equation (10)) [25].<smiles>CC(=O)c1ccc(F)cc1</smiles>

\subsection{Addition of Alcohols}

The synthesis of vinyl ethers can be achieved by a metal-mediated addition of alcohols to alkyne species [26]. McDonald et al. reported the most efficient tungsten-assisted cyclization of alkynols to obtain cyclic vinyl ethers [27]. Nevertheless, 1,3-dicarbonyl compounds tend to suffer keto-enol tautomerization process, and enol species can be $\mathrm{O}$ alkylated under acidic conditions to generate the desired vinyl ether product [28]. On the other hand, a metal-catalyzed carbon-oxygen coupling is an alternative way to synthesize alkoxylated alkene species. The most significant results were obtained with copper(I) (Equation (11)) and copper (II) catalysts (Equation (12)) [29,30].
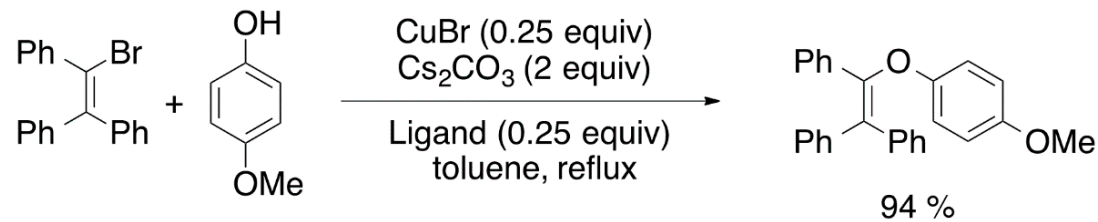<smiles>COc1ccc(OCCN2CCCCC2)cc1</smiles>

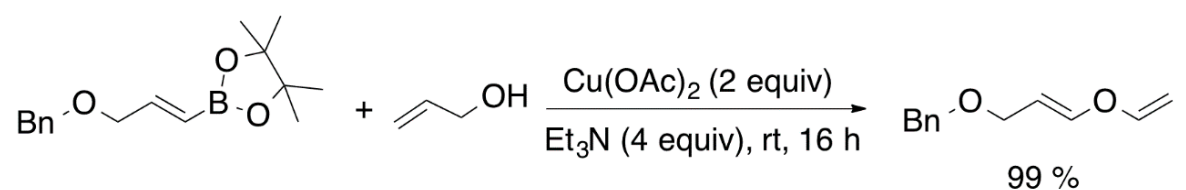

\subsection{Hydroalkoxylation}

Hydroalkoxylation of alkynes is a synthetic tool by which vinyl ethers can be synthesized (Equation (13)). These are of great importance in the chemical industry due to their applications as building blocks of polymers that are used in the production of adhesives, 
paints, plasticizers, thickeners and inks [8]. Normally, this reaction should be catalyzed using molybdenum, tungsten, ruthenium or palladium. On the other hand, platinum, gold, silver, iridium and rhodium-based catalysts have also been able to catalyze the alkoxylation reaction [31].

$$
\mathrm{R}=\mathrm{R}+\mathrm{R}^{\prime} \mathrm{OH} \stackrel{\text { Catalyst }}{\longrightarrow} \mathrm{O}_{\mathrm{O}^{\prime}}^{\mathrm{R}} \stackrel{\mathrm{C}}{\mathrm{H}}
$$

Gold catalysts bearing N-heterocyclic carbene (NHC) ligands are currently being studied due to their high catalytic activity in the alkyne hydroalkoxylation field [32] However, gold catalysts containing NHC ligands in the presence of alkyne compounds can form $\pi$-complexes with an electrophilic character [33] and are capable to carry out a nucleophilic attack by nucleophiles such as alcohols or amines to obtain vinyl amines or ethers [34]. In addition, current reports have revealed that the steric demand from NHC ligands and the solvent effect play a significant role in gold-mediated catalysis. Nolan et al. have reported the lower efficiency of large NHC-gold complexes in the intramolecular hydroalkoxylation of propargylic alcohols [35]. On the other hand, the counterion has been described as an important species in catalysis. In fact, the counterion may help to achieve the nucleophilic attack (Figure 1) due to its coordinating ability, basicity and its morphology [36]. Species with lower basicity, greater coordinating capacity and spherical form tend to decrease the catalytic activity $[37,38]$. The most successful counterions that can efficiently achieve nucleophilic activation are $\mathrm{NTf}_{2}{ }^{-}, \mathrm{OTf}^{-}, \mathrm{OTs}^{-}$and $\mathrm{OMs}^{-}$[39].

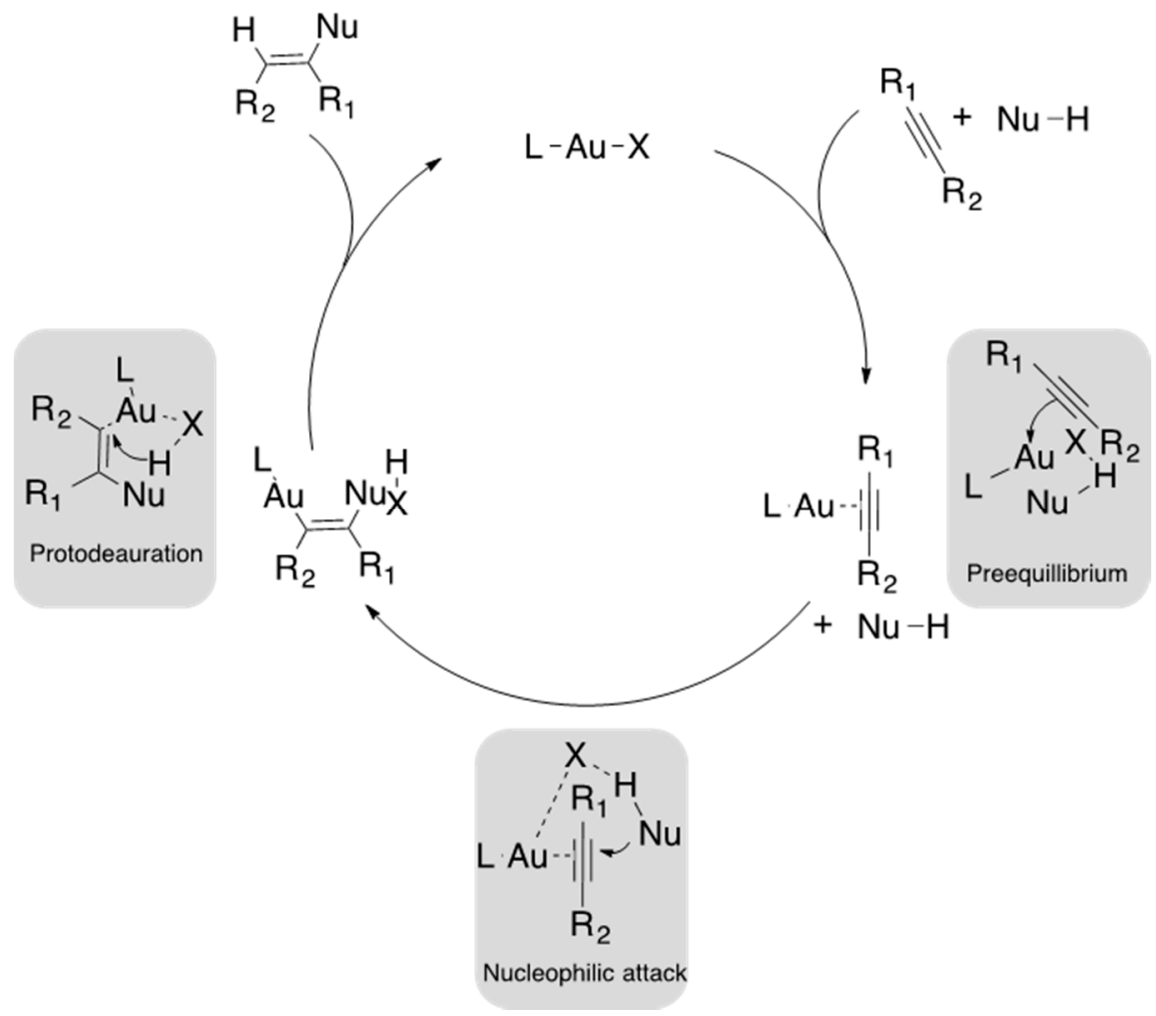

Figure 1. Proposed catalytic cycle of a nucleophilic attack for alkynes by a gold catalyst.

With the help of known information on the hydroalkoxylation reaction, numerous research groups have focused their efforts on the intermolecular hydrophenoxylation of internal alkynes as this transformation turns out to be entropically unfavorable. Efforts to make it work have led to great advances in this field. Kuram et al. have reported the hydrophenoxylation of symmetrical and unsymmetrical alkynes assisted by a gold catalyst in the presence of a mild or strong base (Table 1) [40]. 
Table 1. Hydrophenoxylation of symmetrical alkenes catalyzed by $\mathrm{AuCl}_{3}$.

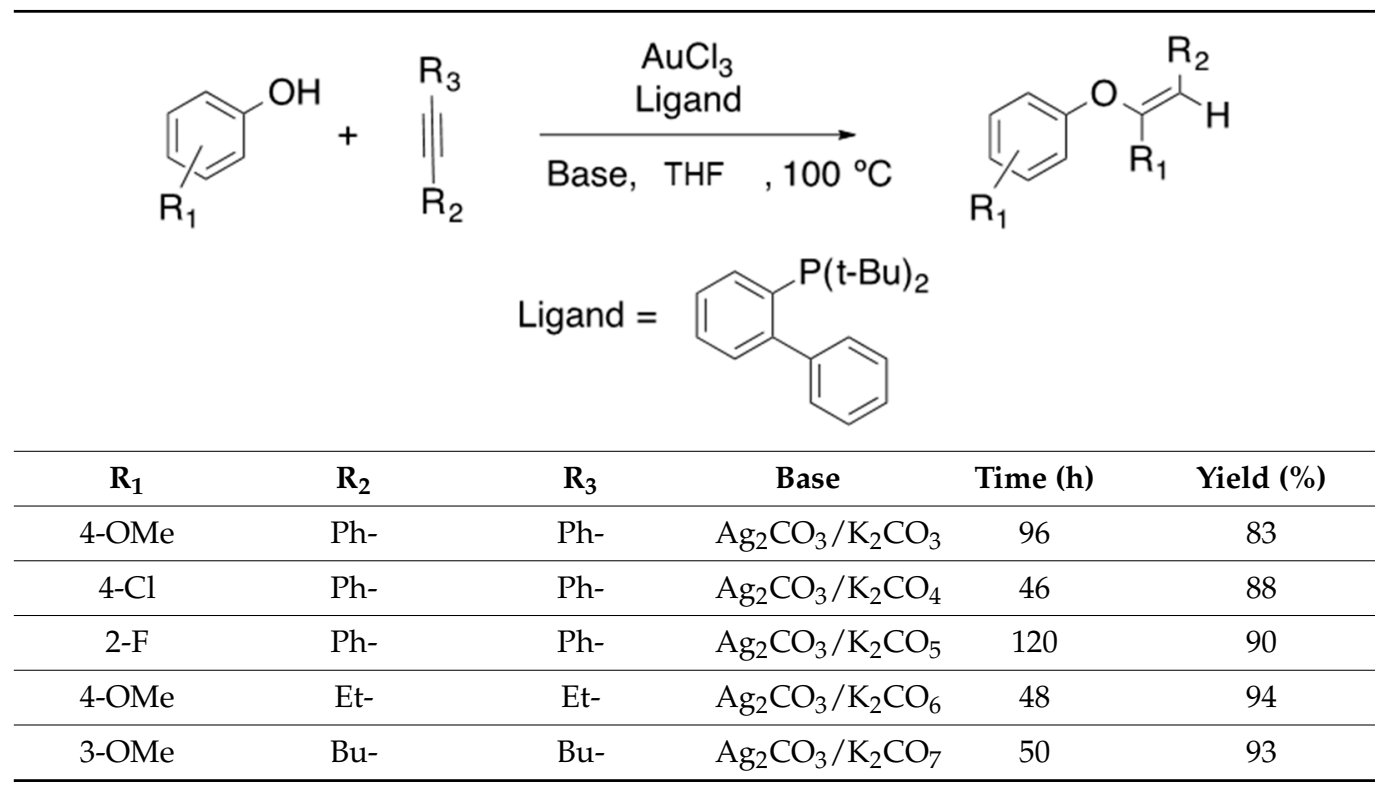

The use of gold catalysts containing sterically rich ligands has become a good methodology to achieve the addition of alcohols to unsaturated bonds. However, the steric hindrance of these ligands can affect the rate determining step (rds) [35]. Nonetheless, the rate of the reaction can be improved by the counterion [36] or polar and protic species [41]. In 2010, Ujaque and coworkers reported the mechanism for the addition of phenols to alkene compounds catalyzed by phosphine-gold catalysts [41]. In their computational mechanistic studies, they proposed a process assisted by phenol and water.

Mechanistically, they proposed the formation of the $\pi$-complex followed by the concerted addition and proton transfer. However, they investigated four possible cases for the rds; (1) direct proton transfer, (2) proton transfer assisted by the counterion (less coordinating ones improve the catalytic performance), (3) proton transfer assisted by phenol and (4) proton transfer assisted by water. They found that the pathway promoted by phenol and water goes through a concerted process. On the other hand, unassisted and anion-assisted processes are unfeasible due to their higher energy barriers (61.1 and $49.6 \mathrm{kcal} / \mathrm{mol}$, respectively) [41].

\subsubsection{Dual Catalysis: An Efficient and Versatile Synthetic Tool}

Dual catalysis has been expanding the catalysis field since the last century. Due to this catalytic strategy, it has been used in processes such as hydroaminomethylation of olefins to obtain amines. However, this reaction was achieved with synthesis gas and ammonia in presence of $\mathrm{Rh} / \mathrm{Ir}$ catalyst under formylation conditions in organic/aqueous phases. In addition, exploring the solvent effect, MTBE was found to be the best organic solvent to obtain selectively primary amines (Scheme 2) [42]. Another catalytic strategy that involves syngas usage is the generation of green fuels such as methanol through the assistance of $\mathrm{Cu} / \mathrm{ZnO}$ and 2-propanol under low temperature conditions [43].

In the synergistic dual transition metal catalysis [44,45], water oxidation catalysis (WOC) was one of the first cases where two metal-oxo units were required to form the $\mathrm{O}-\mathrm{O}$ bond at the rate determining step (rds) of the I2M mechanism [46-48]. However, competition with water nucleophilic attack (WNA) with the interaction of a metal-oxo unit with an $\mathrm{H}_{2} \mathrm{O}$ molecule to form the $\mathrm{O}-\mathrm{O}$ bond has never ceased [49], with the potential role of the non-innocent role of the cerium ammonium nitrate (CAN) [50]. Currently, there is controversy not only related to the kinetic requirements, but to the difficulty of colliding two metal units in low catalyst loading conditions. The latter is a problem in the 
formation of alkanes [51], where two palladium atoms are needed in phosphinesulfonato polymerization catalysis.

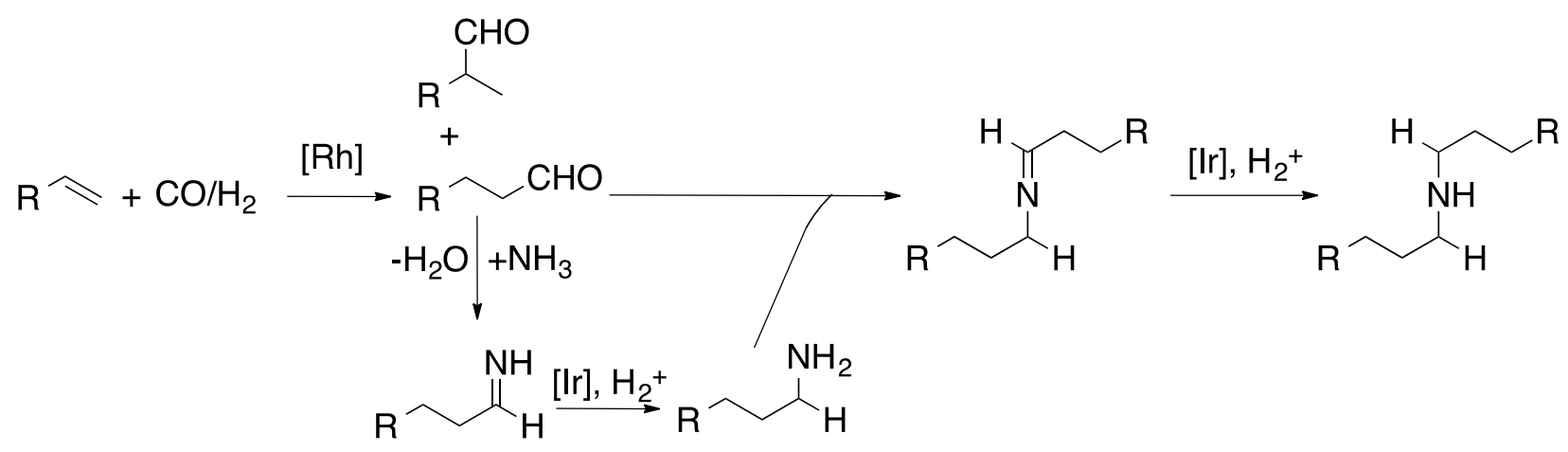

Scheme 2. Generation of the primary and secondary amines in the hydroaminomethylation of olefins assisted by rhodium and iridium catalysts [42].

Another process influenced by dual catalysis has been C-C cross-coupling. In 2010, Bera et al. published the Suzuki and Heck cross-coupling catalyzed by a dipalladium(I) catalyst [52]. Two years later, Schoenebeck and coworkers reported the catalytic activity of dipalladium(I) complexes bridged by halide ligands. Nevertheless, in their report, the C-C cross-coupling catalyzed by palladium(I) dimer was described as a homodual-assisted process $[53,54]$. However, C-C cross-coupling can even be achieved by using heterodual metal catalysis. A clear example of this process is the cross-coupling assisted by $[\mathrm{Pd}(\mathrm{dmpe})$ or $\left(\mathrm{PMe}_{3}\right)_{2}$ ] and vinyl-gold species (Figure 2) [55].

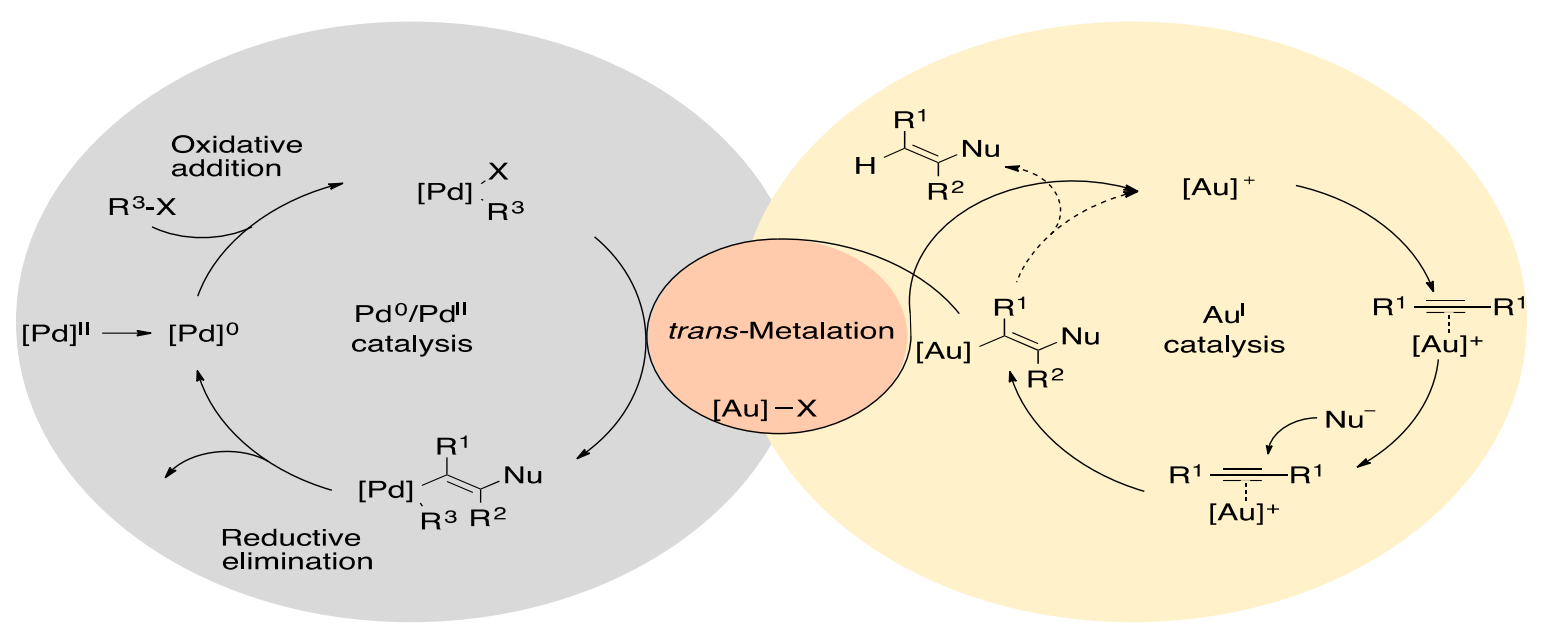

Figure 2. C-C cross-coupling assisted by palladium and gold catalysts [55].

Regarding polymers, dual catalytic systems have provided interesting results. One of the published reports that has been highlighted is the ring-opening polymerization of $\omega$ pentadecatlone catalyzed by DMAP Brønsted base and magnesium halides (Figure 3) [56]. Another achievement in the field has been the polymerization of methacrylate catalyzed by $\left[\mathrm{Et}_{3} \mathrm{SiH}\right] /\left[\mathrm{Et}_{3} \mathrm{Si}(\mathrm{L})\right]^{+}\left[\mathrm{B}\left(\mathrm{C}_{6} \mathrm{~F}_{5}\right)_{4}\right]^{-}$couple, which was described as a good methodology to produce linear polymethacrylates [57]. 


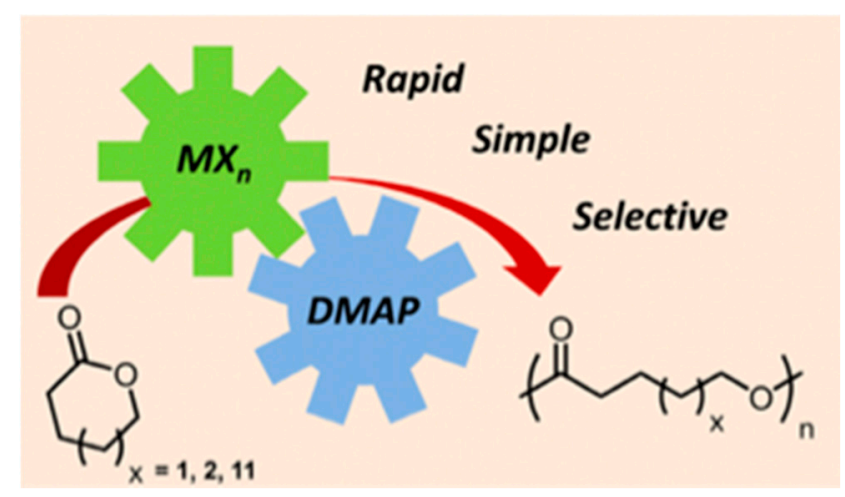

Figure 3. Ring-opening polymerization of lactones [56].

Some fields in chemistry have been positively impacted by the dual-assisted processes, such as asymmetric synthesis. In 2004, Jacobsen et al. achieved the addition of hydrogen cyanide to unsaturated imides assisted by aluminum and lanthanide chiral complexes. In this study, the enantioselectivity was improved by the lanthanide species [58]. Three years after, the field of dual-assisted catalysis was amplified with the enantioselective alkynylation of $\alpha$-amino esters catalyzed by a chiral Brønsted acid and a silver acetate [59]. More interesting studies were then added to this field, such as the enantioselective [2+2] photocycloaddition between two unsaturated ketones. The cycloaddition reaction was promoted with visible light in the presence of ruthenium catalyst and a chiral Lewis acid (Figure 4) [60].

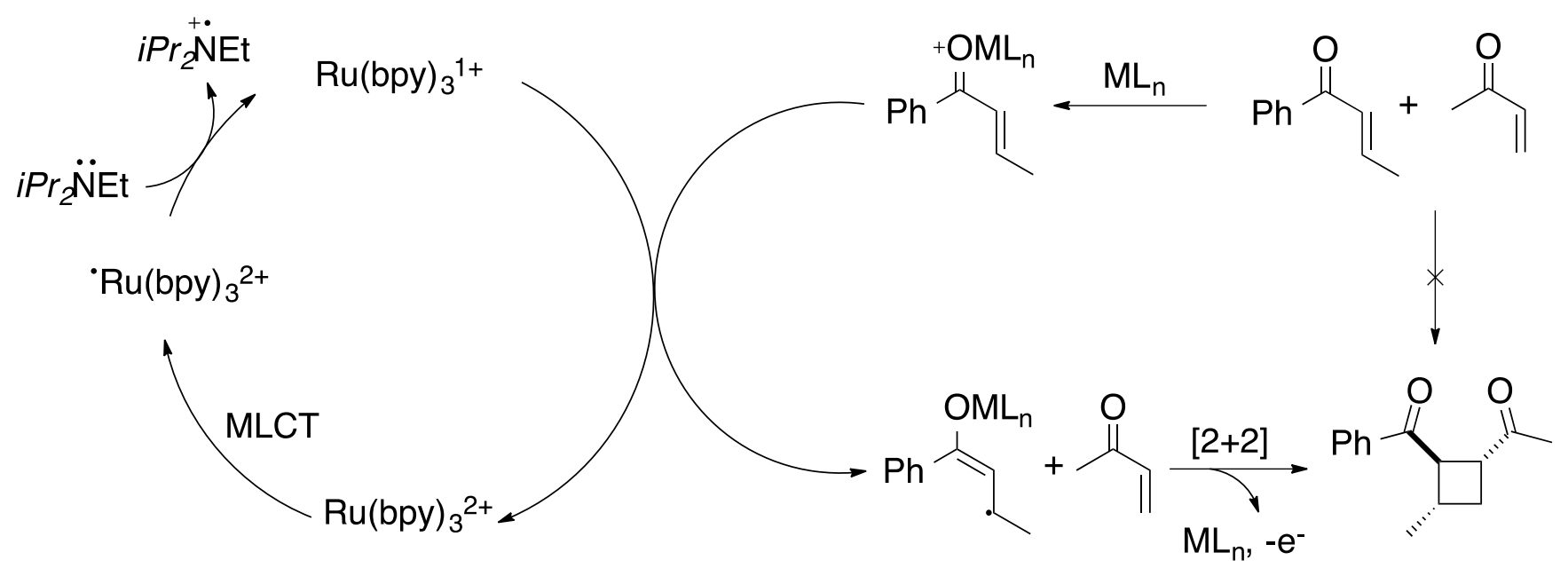

Figure 4. Enantioselective [2+2] cycloaddition [60].

As we have seen, Brønsted acids, together with Lewis acids, are able to catalyze enantioselective reactions, but Lewis acids in combination with a Schiff base have carried out a wide variety of homodual- and heterodual-assisted processes, providing a wide range of asymmetric transformations. For instance, asymmetric reactions, such as an amination, Mannich and aziridine opening, were achieved using bimetallic complexes bearing Schiff bases obtaining products with a higher percentage of enantiomeric excess (Figure 5) [61]. 


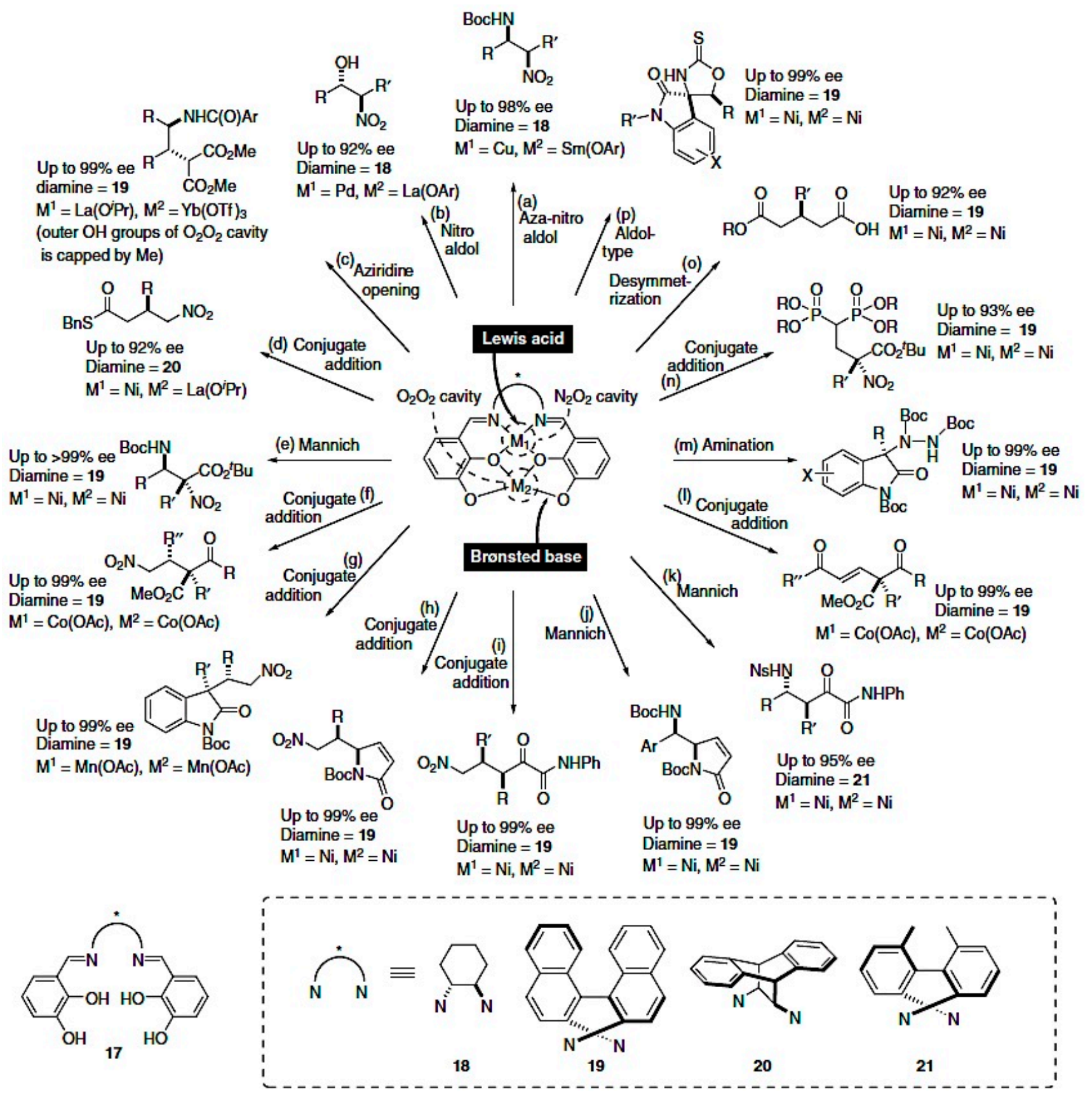

Figure 5. Asymmetric transformations catalyzed by a Lewis acid/Brønsted base [61].

Catalysis involving a Lewis acid-Lewis base couple has promoted a wide variety of processes due to its characteristic interaction with the substrate by which it is activated (Figure 6). Some examples are the enantioselective reduction of ketones catalyzed by borane/oxazaborolidines [62], alkylation of aldehydes [63] and ketones [64] assisted by a Zn-salen catalyst, enantioselective allylation of aldehydes directed by a silver-(R)-BINAP complex [65] and even the diastereoselective condensation reaction, such as aldol [66] and Mannich [67]. 


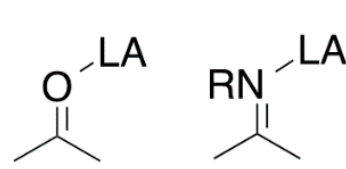

a)

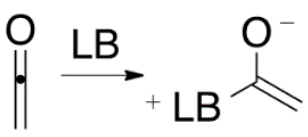

c)<smiles>C=CC(=O)CCCCC=C[O-]</smiles>

b)<smiles>C=CC=CC=O</smiles>

d)
Nucleophile

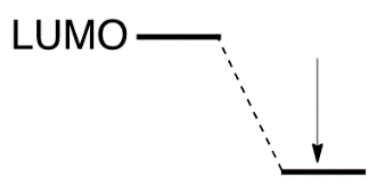

Figure 6. (a) Activation of the electrophile by a Lewis acid. (b-d) Activation of the nucleophile by a Lewis base. (e) Frontier orbitals of the activated nucleophile and electrophile.

Cooperative catalysis has been applied to carry out processes such as asymmetric hydrogenation of ketones, where the ligand and the metal assist the reaction synergistically. The most known reported catalysts are $\mathrm{Ru}$-(phosphine) ${ }_{2}$-amine [68] and Feamine(imine)diphosphine [69,70]. This type of catalyst can achieve the hydrogen transfer through a dual-assisted metal-nitrogen process (Figure 7).

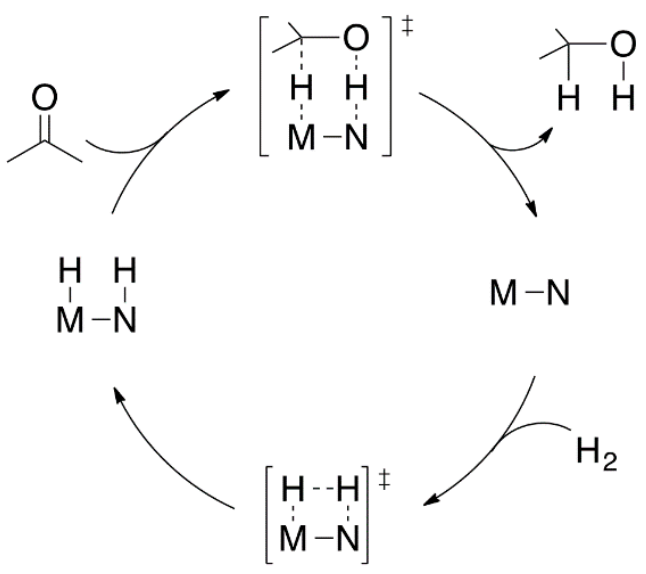

Figure 7. Metal-nitrogen activation in asymmetric hydrogenation of non-symmetric ketones.

On the other hand, dual cooperative catalysis has been exploited in the field of biomimetic chemistry. In this field, an enzyme together with a metal carry out a wide variety synergistic processes, such as regeneration of nicotinamide [71], biotransformations; enantioselective hydrolysis of esters [72], acylation [73], asymmetric polymerization [74], epoxidation of fatty acids [75] and conversion of $\mathrm{N}$-acetyl amino acrylates to amino acids [76]. Already related to the catalysis of $\mathrm{Au}(\mathrm{I})$, the central subject of this article, the dual metal solution to mechanisms previously thought with a single metallic unit allowed, for example, to understand the $\mathrm{Au}(\mathrm{I})$ catalyzed hydroarylation of alkenes with $\mathrm{N}$, $\mathrm{N}$-dialkylanilines (see the article by Abdellah et al. [77]).

\subsubsection{Dual-Assisted Hydroalkoxylation Process}

In recent years, dual or cooperative catalysis has been described as a powerful tool that improves the selectivity and reactivity in organic reactions [78-80]. In 2008, Toste et al. published the dual-gold-catalyzed cycloisomerization of 1,5-allenynes [81]. In 2010, these results caught the attention of Nolan and coworkers and inspired them to achieve the synthesis of gem-digold $\left[\left\{\mathrm{Au}\left(\mathrm{PPh}_{3}\right)\right\}_{2}(\mu-\mathrm{OH})\right]\left[\mathrm{BF}_{4}\right]$ that provided a new overview of gold catalysis (eq 14) [82]. Later, Widenhoefer et al. reported on the $\sigma, \pi$-alkyne activation 
(Equation (15)) [83]. Di-gold $\sigma, \pi$-acetylide complexes in absence of base were synthesized. Due to their easy access and properties, they are considered as intermediates in digold catalysis involving terminal alkynes.

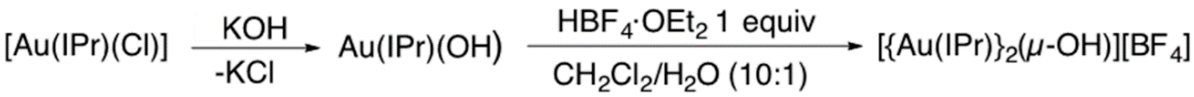

$$
\begin{aligned}
& \operatorname{Pr}=[
\end{aligned}
$$

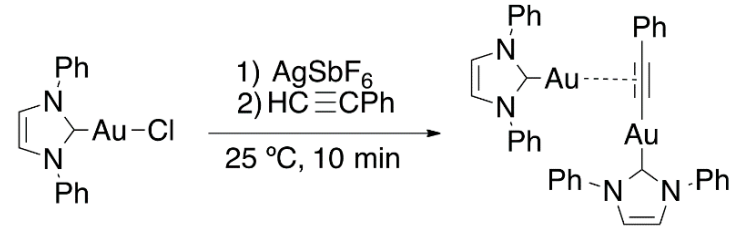

$$
\begin{aligned}
& 99 \%
\end{aligned}
$$

Promising progress in dual-gold-assisted catalysis attracted the attention of Roithová and coworkers, who focused their efforts on exploring the hydroalkoxylation mechanism using ESI-MS and DFT calculations. They observed a competitive mono- and di-gold mechanism for hydromethoxylation of 1-phenyl-propyne, due to the success of the methodology. In 2015, they reported on a new computational-experimental strategy to analyze the intermediates in gold catalysis (Figure 8) [84-87].

Another interesting computational mechanistic study on dual-gold catalysis was published by Hashmi et al. in 2015 [88]. It discussed the improvement of the rate determining step via mono- or di-gold catalyst transfer from $\mathrm{C}-[\mathrm{M}]_{2}$ compounds to nonactivated terminal alkyne species. Focusing on the proton transfer, they found a higher energy barrier for single gold catalyst transfer pathway $(46.9 \mathrm{kcal} / \mathrm{mol})$, being favored the dual-assisted process $(29.5 \mathrm{kcal} / \mathrm{mol})$.

In 2013, the synthesis of a gem-digold compound by Nolan et al. allowed alkyne hydrophenoxylation (Equation (16)), catalyzed by this di-gold hydroxide species, under relatively mild conditions [89]. The passion for vinyl ethers synthesis inspired Nolan's group to achieve intermolecular hydroalkoxylation (Equation (17)), with a selectivity of $90 \%$, and hydrocarboxylation (Equation (18)) of internal alkynes [90,91].

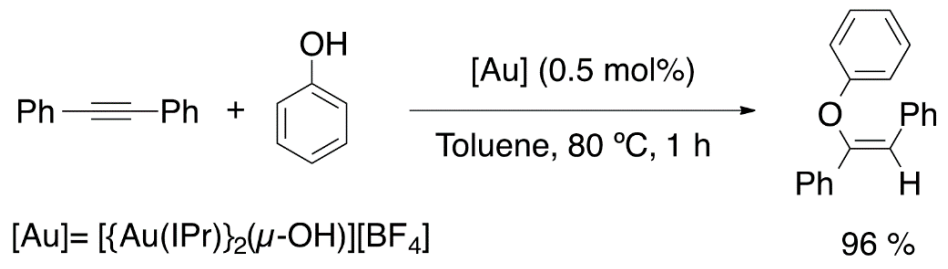

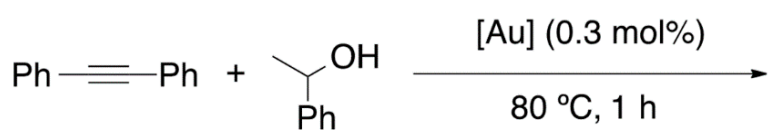

1.1 equiv<smiles>CC(O/C(=C/[PH2+]c1ccccc1)c1ccccc1)/C(=C/c1ccccc1)c1ccccc1</smiles>

$>99 \%(9 / 1)$

$[\mathrm{Au}]=\left[\{\mathrm{Au}(\mathrm{SIPr})\}_{2}(\mu-\mathrm{OH})\right]\left[\mathrm{BF}_{4}\right]$ 


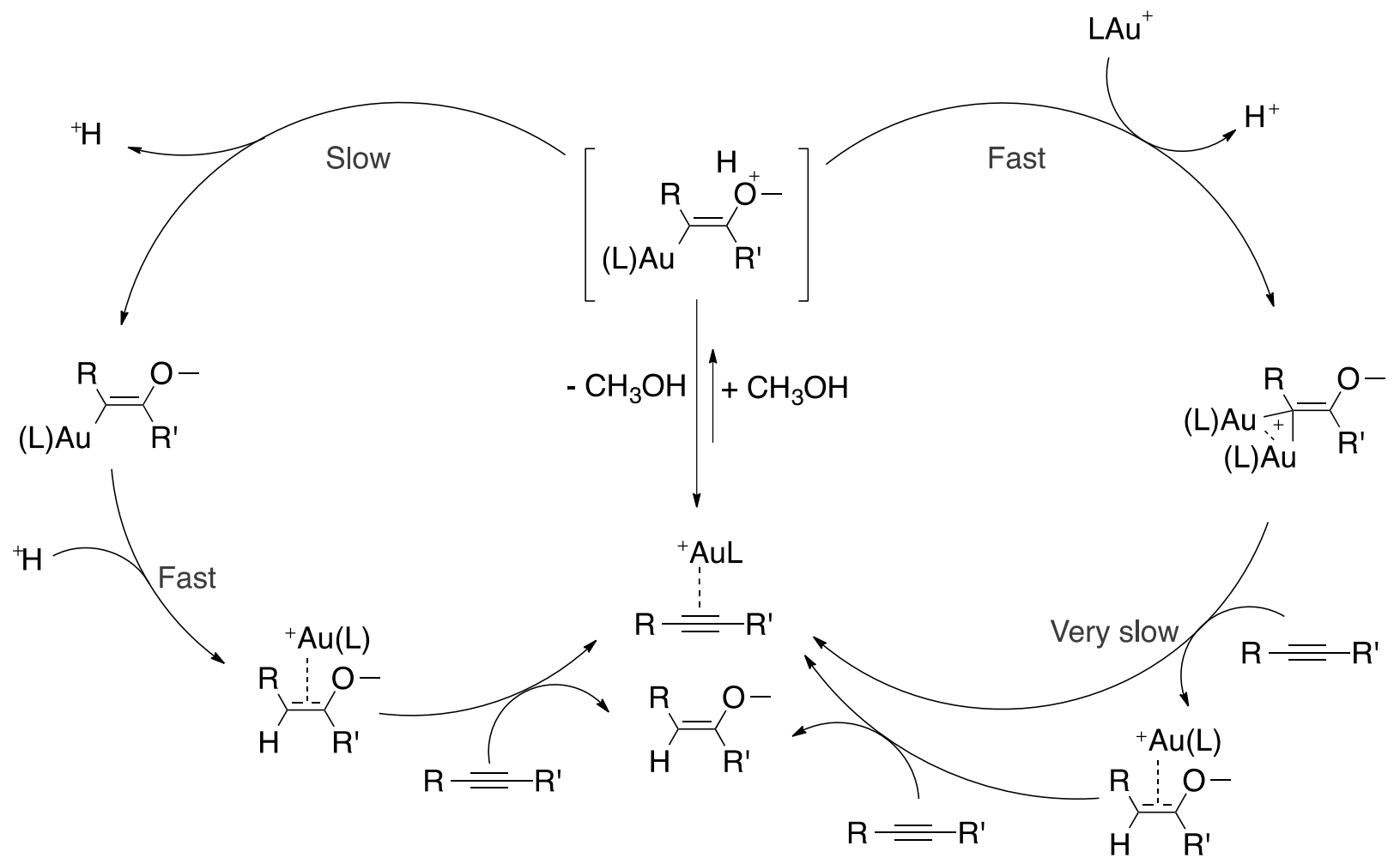

Protodeuration

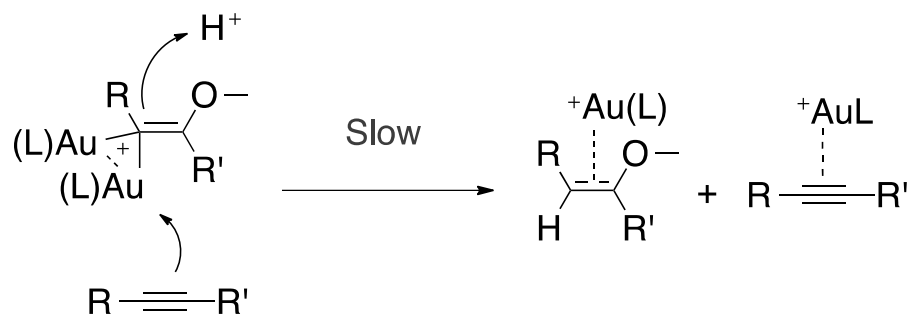

Figure 8. Reaction mechanism of alkyne hydromethoxylation assisted by mono- or diaurated species containing hindered ligands.

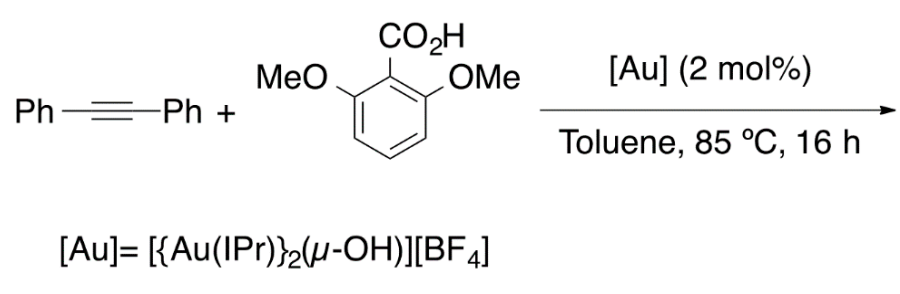

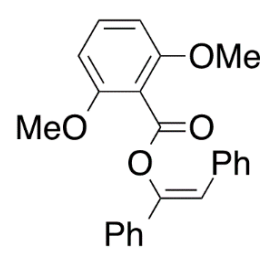

$>99 \%$

Taking as a starting point the equilibrium between the gem-digold compound and the alkyne-gold complex, Poater et al. proposed a mechanism that involves the active species included in Figure 9. On the reaction pathway, the reactive species alkyne-[Au] and $\mathrm{PhO}-[\mathrm{Au}]$ are formed in the initiation part and regenerated during the catalytic cycle. Overall, the process is described as a nucleophilic attack followed by displacement and protonation reactions. Moreover, the nucleophilic attack that involves the $\mathrm{C}-\mathrm{O}$ bond formation was found to be the rate determining step [91]. On the other hand, Reek et al. confirmed that the hydrophenoxylation of alkynes enhanced when encapsulating the gold catalyst in encapsulated in self-assembled resorcinarene cage $[92,93]$. Thus, this is a clear 
confirmation that the dual gold catalysis takes place for the hydrophenoxylation of alkynes. Moreover, predictive catalytic results by DFT calculations proposed a new generation of digold complexes [94], where both metal moieties are linked by an alkylic bridge.

Initiation

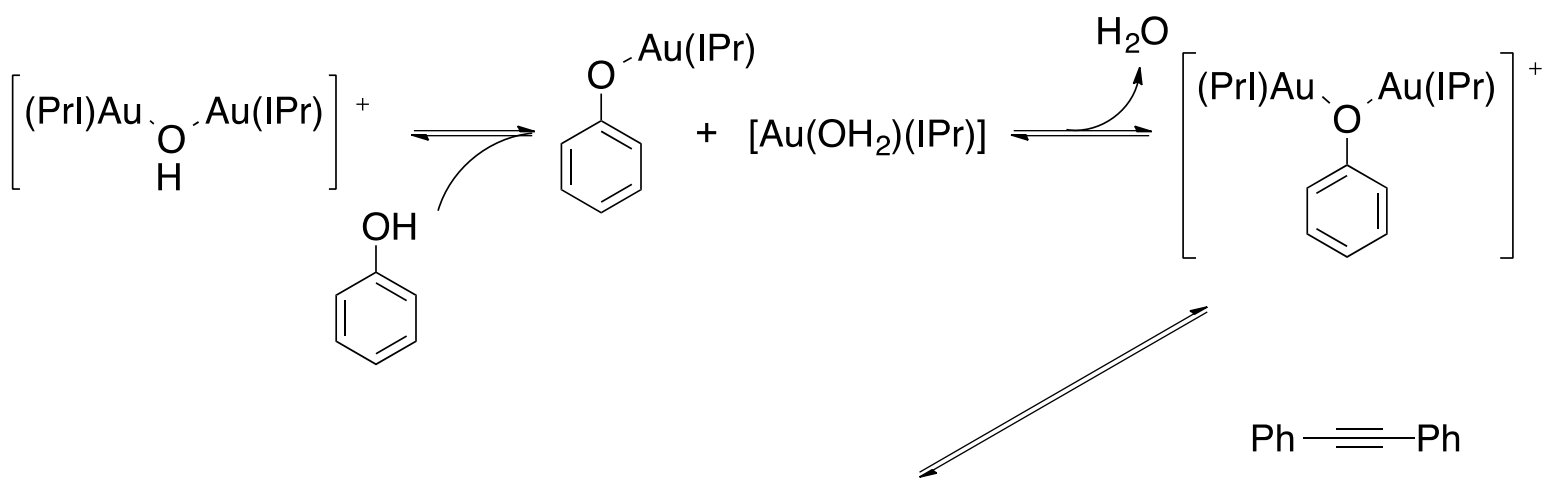

Main catalytic cycle

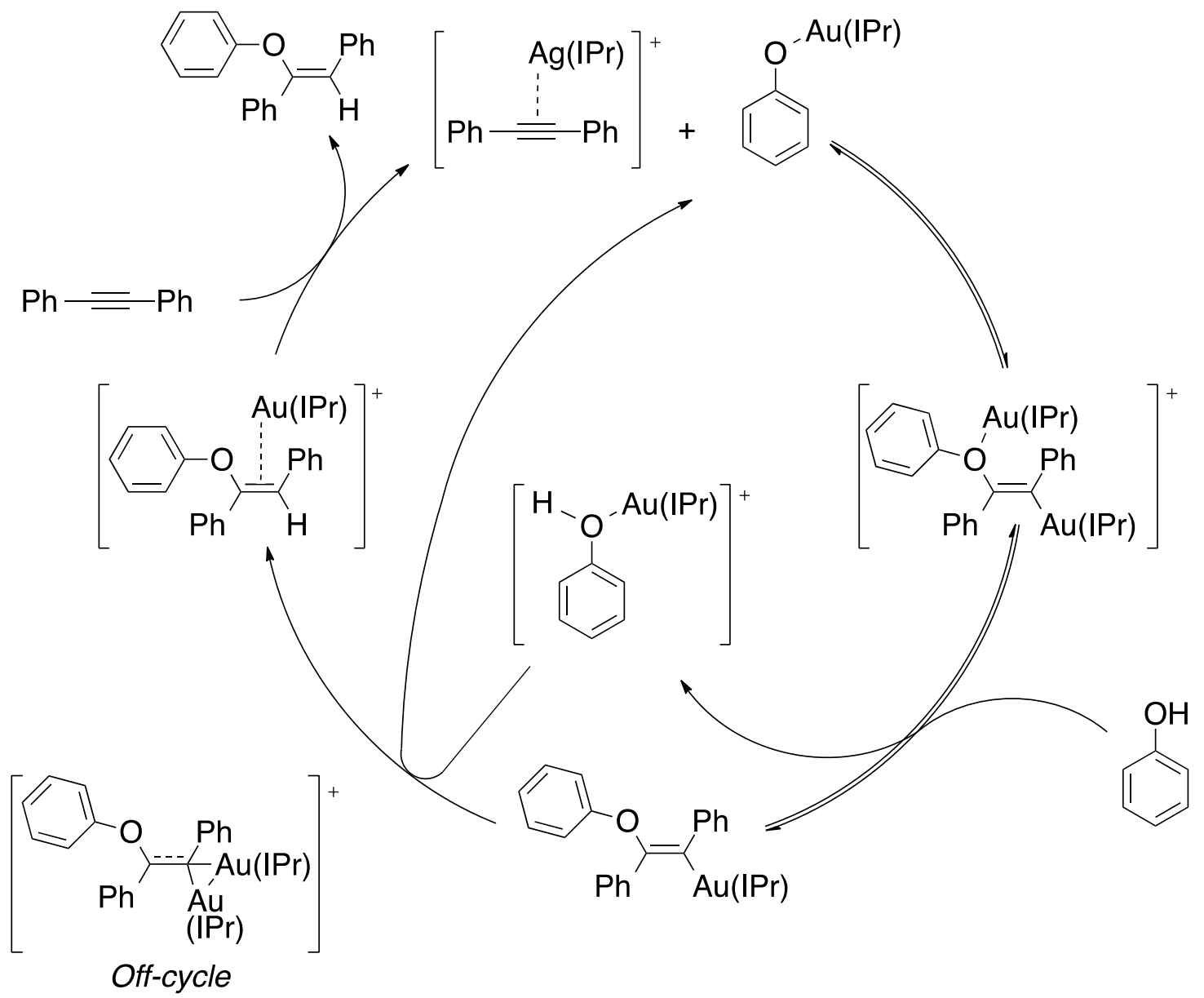

Figure 9. Reaction mechanism for di-gold-assisted hydrophenoxylation of diphenylacetylene.

Recently, Cazin et al. have reported the hydrophenoxylation of diphenylacetylene catalyzed by a combined $\mathrm{Cu}(\mathrm{NHC}) / \mathrm{Au}(\mathrm{NHC})$ catalytic system [95]. Nevertheless, they performed experimental studies to determine the solvent and temperature effect in the hydrophenoxylation reaction and they found a higher conversion to the desired product under solvent-free conditions. Once the optimal conditions were found, they tested the 
addition of substituted phenols to diphenylacetylene observing conversions of up to $90 \%$ of the desired vinyl ether (Equation (19)).
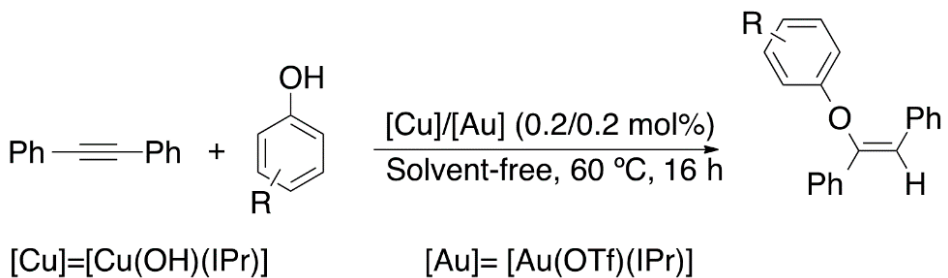

$[\mathrm{Cu}]=[\mathrm{Cu}(\mathrm{OH})(\mathrm{IPr})]$

$[\mathrm{Au}]=[\mathrm{Au}(\mathrm{OTf})(\mathrm{IPr})]$

$\mathrm{R}=\mathrm{H}(99 \%)$, Me $(99 \%)$ or OMe $(99 \%)$

On the other hand, Cazin and coworkers performed some mechanistic studies to elucidate the mechanism by which the reaction proceeds (Figure 10). All in all, the performed stoichiometric reactions reveal the generation of the activated species $[\mathrm{Cu}(\mathrm{OPh})(\mathrm{IPr})]$ and $[\mathrm{Au}(\mathrm{PhCCPh})(\mathrm{IPr})]$ and their importance in the catalytic process [95]. Subsequent DFT calculations confirmed that the mixed dual metal system was better than the di-gold one [96]. Specifically, gold is associated with the alkyne, while phenoxide with copper, although with silver, the mixed system would be even more favorable [97].
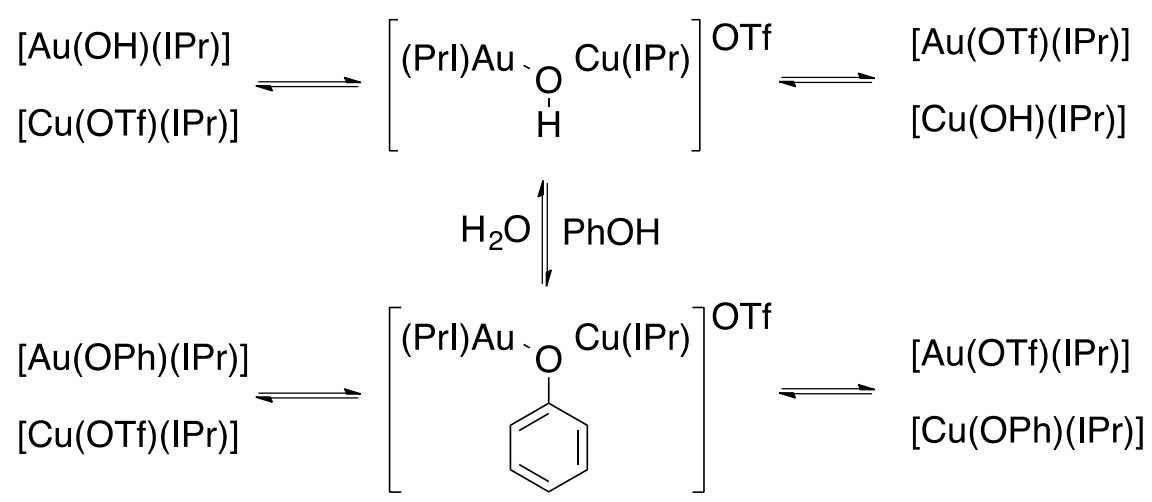<smiles>Oc1ccccc1</smiles>

$[\mathrm{Cu}(\mathrm{OTf})(\mathrm{IPr})]$

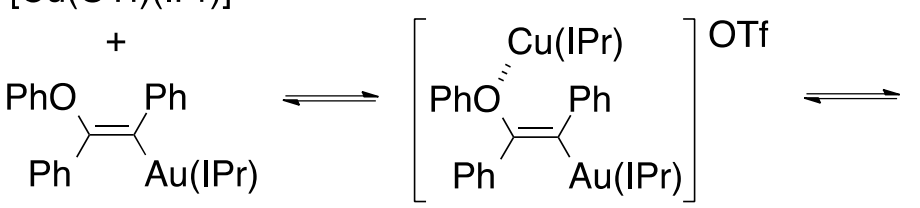

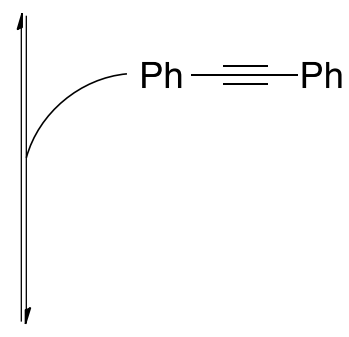

[Cu(OPh)(IPr)]

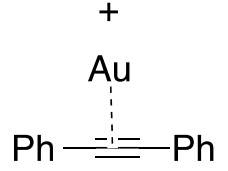

Figure 10. Mechanism for the hydrophenoxylation of internal alkynes assisted by a gold/copper catalyst.

Nevertheless, for alkyl alcohols, the dual mechanism has not been tested so far, and at a computational DFT level, it is understood that it is the anion interaction that facilitates the hydroalkoxylation promoted by gold (I) catalysts with such substrates [37]. The boundary between mono and dual metal catalysis is very fine [98,99], and thus, simple modifications of the nature of the substrates and simple modifications in the metal ligands can completely exclude dual catalysis $[100,101]$. 


\section{Conclusions}

The functionalization of alkynes assisted by the catalytic role of $\mathrm{Au}(\mathrm{NHC})$ complexes includes, among others, the hydrophenoxylation reaction. This reaction is paradigmatic since its mono/dual gold character has not been confirmed yet because of somewhat unclear experimental kinetics. However, Reek and Nolan confirmed the dual catalysis character for such a reaction with the encapsulation of the catalyst, apart from DFT calculations by Houk and Poater. Although it may seem like a confusing reaction, the synergy of metal centers does not only assist the hydrophenoxylation of alkynes-it also paves the way for possible solutions in other reactions.

Author Contributions: All authors have contributed equally to write the manuscript. All authors have read and agreed to the published version of the manuscript.

Funding: This research was funded by the Ministerio de Economía y Competitividad (MINECO) of Spain for project PGC2018-097722-B-I00, the Generalitat de Catalunya for project 2017SGR39 and Xarxa de Referència en Química Teórica i Computacional. O.F.G.-B. thanks the Universidad de Guanajuato for funding his Master Thesis.

Data Availability Statement: Data sharing not applicable since no datasets were generated or analyzed during the current study.

Acknowledgments: A.P. is a Serra Húnter Fellow and thanks the ICREA Academia prize 2019.

Conflicts of Interest: The authors declare no conflict of interest.

\section{References}

1. Kenly, S.J. Encyclopedia of Catalysis; John Wiley and Sons, Inc.: Hoboken, NJ, USA, 2010; pp. 1-30.

2. Sabatier, P. How I Have Been Led to the Direct Hydrogenation Method by Metallic Catalysts. Ind. Eng. Chem. 1926, 18, 1005-1008. [CrossRef]

3. American Chemical Society National Historic Chemical Landmarks. The Houdry Process for Catalytic Cracking. Available online: http:/ / www.acs.org/content/acs/en/education/whatischemistry/landmaks/houdry.html (accessed on 23 May 2017).

4. Smith, J.K.; Spitz, P.H. Petrochemicals: The Rise of an Industry. Technol. Cult. 1989, 30, 710. [CrossRef]

5. Worthy, W. Canadian chemical firms: Another good year. Chem. Eng. News 1979, 57, 17. [CrossRef]

6. Weirsselmel, K.; Arpe, H.J. Industrial Organic Chemistry, 3rd ed.; VCH Publishers, Inc.: New York, NY, USA, 1997 ; p. 218.

7. Available online: http://www.dupont.com/corporate-functions/our-company/dupont-history.html (accessed on 15 November 2020).

8. Schröder, G. Ullmann's Encyclopedia of Industrial Chemistry; John Wiley and Sons, Inc.: Hoboken, NJ, USA, 2012; Volume 28, pp. $481-485$.

9. Okimoto, Y.; Sakaguchi, S.; Ishii, Y. Development of a Highly Efficient Catalytic Method for Synthesis of Vinyl Ethers. J. Am. Chem. Soc. 2002, 124, 1590-1591. [CrossRef] [PubMed]

10. Bosch, M.; Schlaf, M. Synthesis of Allyl and Alkyl Vinyl Ethers Using an in Situ Prepared Air-Stable Palladium Catalyst. Efficient Transfer Vinylation of Primary, Secondary, and Tertiary Alcohols. J. Org. Chem. 2003, 68, 5225-5227. [CrossRef]

11. Nakamura, A.; Tokunaga, M. Au(I) complexes-catalyzed transfer vinylation of alcohols and carboxylic acids. Tetrahedron Lett. 2008, 49, 3729-3732. [CrossRef]

12. Charbonnier, F.; Moyano, A.; Greene, A.E. Facile synthesis of chiral Oalkyl enol ethers. J. Org. Chem. 1987, 52, 2303-2306. [CrossRef]

13. Sageot, O.; Monteux, D.; Langlois, Y.; Riche, C.; Chiaroni, A. Preparation and use of chiral (Z)-enol ethers in asymmetric bradsher cycloaddition. Tetrahedron Lett. 1996, 37, 7019-7022. [CrossRef]

14. Aloui, M.; Chambers, D.J.; Cumpstey, I.; Fairbanks, A.J.; Redgrave, A.J.; Seward, C.M.P. Stereoselective 1,2-cis Glycosylation of 2-O-Allyl Protected Thioglycosides. Chem. Eur. J. 2002, 8, 2608-2621. [CrossRef]

15. Crivello, J.V.; Kong, S. Efficient Isomerization of Allyl Ethers and Related Compounds Using Pentacarbonyliron. J. Org. Chem. 1998, 63, 6745-6748. [CrossRef]

16. Roche, C.; Delair, P.; Greene, A.E. Dichloroketene-Chiral Olefin-Based Approach to Pyrrolizidines: Highly Stereocontrolled Synthesis of (+)-Amphorogynine A. Org. Lett. 2003, 5, 1741-1744. [CrossRef]

17. Mizuno, K.; Kimura, Y.; Otsuji, Y. A Convenient Synthesis of Aryl Vinyl Ethers by Use of Tetra-n-butylammonium Hydrogen Sulfate. Synthesis 1979, 1979, 688. [CrossRef]

18. Hiersemann, M. Synthesis of $\alpha$-Allyloxy-Substituted $\alpha, \beta$-Unsaturated Esters via Aldol Condensation. Convenient Access of Highly Substituted Allyl Vinyl Ethers. Synthesis 2000, 2000, 1279-1290. [CrossRef]

19. Park, H.G.; Kim, D.H.; Yoo, M.S.; Park, M.K.; Jew, S.S. Practical regioselective synthetic method for (E)-enol ether. Tetrahedron Lett. 2000, 41, 4579-4582. [CrossRef] 
20. Maeda, K.; Shinokubo, H.; Oshima, K.; Utimoto, K. Stereoselective Synthesis of Allyl Vinyl Ethers from Silyl Enol Ethers. J. Org. Chem. 1996, 61, 2262-2263. [CrossRef]

21. Hoffmann, R.W. Wittig and His Accomplishments: Still Relevant Beyond His 100th Birthday. Angew. Chem. Int. Ed. 2001, 40, 1411-1416. [CrossRef]

22. Julia, M.; Paris, J.-M. Syntheses a l'aide de sulfones v(+)-methode de synthese generale de doubles liaisons. Tetrahedron Lett. 1973, 14, 4833-4836. [CrossRef]

23. Sabitha, G.; Reddy, M.M.; Srinivas, D.; Yadov, J. Microwave irradiation: Wittig olefination of lactones and amides. Tetrahedron Lett. 1999, 40, 165-166. [CrossRef]

24. Kulkarni, M.; Dhondge, A.; Borhade, A.; Gaikwad, D.; Chavhan, S.; Shaikh, Y.; Nigdale, V.; Desai, M.; Birhade, D.; Shinde, M. Total Synthesis of $( \pm)$-Physovenine. Eur. J. Org. Chem. 2009, 23, 3875-3877. [CrossRef]

25. Surprenant, S.; Chan, W.Y.; Berthelette, C. Efficient Synthesis of Substituted Vinyl Ethers Using the Julia Olefination. Org. Lett. 2003, 5, 4851-4854. [CrossRef]

26. Alonso, F.; Beletskaya, I.P.; Yus, M. Transition-Metal-Catalyzed Addition of Heteroatom-Hydrogen Bonds to Alkynes. Chem. Rev. 2004, 104, 3079-3160. [CrossRef]

27. Alcazar, E.; Pletcher, J.M.; McDonald, F.E. Synthesis of Seven-Membered Ring Glycals via endo-Selective Alkynol Cycloisomerization. Org. Lett. 2004, 6, 3877-3880. [CrossRef]

28. Danishefsky, S.J.; DeNinno, M.P.; Chen, S.H. Stereoselective total syntheses of the naturally occurring enantiomers of Nacetylneuraminic acid and 3-deoxy-D-manno-2-octulosonic acid. A new and stereospecific approach to sialo and 3-deoxy-Dmanno-2-octulosonic acid conjugates. J. Am. Chem. Soc. 1988, 110, 3929-3940. [CrossRef]

29. Wan, Z.; Jones, C.D.; Koenig, T.M.; Pu, Y.J.; Mitchell, D. Vinyl aryl ethers from copper-catalyzed coupling of vinyl halides and phenols. Tetrahedron Lett. 2003, 44, 8257-8259. [CrossRef]

30. Shade, R.E.; Hyde, A.M.; Olsen, J.-C.; Merlic, C.A. Copper-Promoted Coupling of Vinyl Boronates and Alcohols: A Mild Synthesis of Allyl Vinyl Ethers. J. Am. Chem. Soc. 2010, 132, 1202-1203. [CrossRef]

31. Messerle, B.A.; Vuong, K.Q. Rhodium- and Iridium-Catalyzed Double Hydroalkoxylation of Alkynes, an Efficient Method for the Synthesis of O,O-Acetals: Catalytic and Mechanistic Studies. Organometallics 2007, 26, 3031-3040. [CrossRef]

32. Hopkinson, M.N.; Richter, C.; Schedler, M.; Glorius, F. An overview of N-heterocyclic carbenes. Nat. Cell Biol. 2014, 510, 485-496. [CrossRef]

33. Leung, C.H.; Baron, M.; Biffis, A. Gold-Catalyzed Intermolecular Alkyne Hydrofunctionalizations-Mechanistic Insights. Catalysts 2020, 10, 1210. [CrossRef]

34. Brooner, R.E.M.; Widenhoefer, R.A. Cationic, Two-Coordinate Gold $\pi$ Complexes. Angew. Chem. Int. Ed. 2013, 52, 11714-11724. [CrossRef]

35. Gomez, S.A.; Ramon, S.R.; Songis, O.; Slawin, A.M.Z.; Cazin, C.S.J.; Nolan, S.P. Influence of a Very Bulky N-Heterocyclic Carbene in Gold-Mediated Catalysis. Organometallics 2011, 30, 5463-5470. [CrossRef]

36. Biasiolo, L.; Del Zotto, A.; Zuccaccia, D. Toward Optimizing the Performance of Homogeneous L-Au-X Catalysts through Appropriate Matching of the Ligand (L) and Counterion (X-). Organometallics 2015, 34, 1759-1765. [CrossRef]

37. D'Amore, L.; Ciancaleoni, G.; Belpassi, L.; Tarantelli, F.; Zuccaccia, D.; Belanzoni, P. Unraveling the Anion/Ligand Interplay in the Reaction Mechanism of Gold(I)-Catalyzed Alkoxylation of Alkynes. Organometallics 2017, 36, 2364-2376. [CrossRef]

38. Ciancaleoni, G.; Belpassi, L.; Zuccaccia, D.; Tarantelli, F.; Belanzoni, P. Counterion Effect in the Reaction Mechanism of NHC Gold(I)-Catalyzed Alkoxylation of Alkynes: Computational Insight into Experiment. ACS Catal. 2015, 5, 803-814. [CrossRef]

39. Trinchillo, M.; Belanzoni, P.; Belpassi, L.; Biasiolo, L.; Busico, V.; D’Amora, A.; D'Amore, L.; Del Zotto, A.; Tarantelli, F.; Tuzi, A.; et al. Extensive Experimental and Computational Study of Counterion Effect in the Reaction Mechanism of NHC-Gold(I)Catalyzed Alkoxylation of Alkynes. Organometallics 2016, 35, 641-654. [CrossRef]

40. Kuram, M.R.; Bhanuchandra, M.; Sahoo, A.K. Gold-Catalyzed Intermolecular Hydrophenoxylation of Unactivated Internal Alkynes. J. Org. Chem. 2010, 75, 2247-2258. [CrossRef]

41. Kovács, G.; Lledós, A.; Ujaque, G. Reaction Mechanism of the Gold(I)-Catalyzed Addition of Phenols to Olefins: A Concerted Process Accelerated by Phenol and Water. Organometallics 2010, 29, 3252-3260. [CrossRef]

42. Zimmermann, B.; Herwing, J.; Beller, M. The First Efficient Hydroaminomethylation with Ammonia: With Dual Metal Catalysts and Two-Phase Catalysis to Primary Amines. Angew. Chem. Int. Ed. 1999, 38, 2372-3275. [CrossRef]

43. Yang, R.; Zhang, Y.; Tsubaki, N. Dual catalysis mechanism of alcohol solvent and Cu catalyst for a new methanol synthesis method. Catal. Commun. 2005, 6, 275-279. [CrossRef]

44. Bin Kim, U.; Jung, D.J.; Jeon, H.J.; Rathwell, K.; Lee, S.-G. Synergistic Dual Transition Metal Catalysis. Chem. Rev. 2020, 120, 13382-13433. [CrossRef]

45. Chen, Z.-S.; Huang, L.-Z.; Jeon, H.J.; Xuan, Z.; Lee, S.-G. Cooperative Pd(0)/Rh(II) Dual Catalysis: Interceptive Capturing of $\pi$-Allyl Pd(II) Complexes with $\alpha$-Imino Rh(II) Carbenoids. ACS Catal. 2016, 6, 4914-4919. [CrossRef]

46. Bozoglian, F.; Romain, S.; Ertem, M.Z.; Todorova, T.K.; Sens, C.; Mola, J.; Rodriguez, M.; Romero, I.; Benet-Buchholz, J.; Fontrodona, X.; et al. The Ru-Hbpp water oxidation catalyst. J. Am. Chem. Soc. 2009, 131, 15176-15187. [CrossRef]

47. Richmond, C.J.; Matheu, R.; Poater, A.; Falivene, L.; Benet-Buchholz, J.; Sala, X.; Cavallo, L.; Llobet, A. Supramolecular Water Oxidation with Ru-bda-Based Catalysts. Chem. Eur. J. 2014, 20, 17282-17286. [CrossRef] [PubMed] 
48. Richmond, C.J.; Escayola, S.; Poater, A. Axial Ligand Effects of Ru-BDA Complexes in the O-O Bond Formation via the I2M Bimolecular Mechanism in Water Oxidation Catalysis. Eur. J. Inorg. Chem. 2019, 2019, 2101-2108. [CrossRef]

49. Luque-Urrutia, J.A.; Kamdar, J.M.; Grotjahn, D.B.; Solà, M.; Poater, A. Understanding the Performance of a Bisphosphonate Ru Water Oxidation Catalyst. Dalton Trans. 2020, 49, 14052-14060. [CrossRef]

50. Bucci, A.; Rodriguez, G.M.; Bellachioma, G.; Zuccaccia, C.; Poater, A.; Cavallo, L.; Macchioni, A. An Alternative Reaction Pathway for Iridium-Catalyzed Water Oxidation Driven by Cerium Ammonium Nitrate (CAN). ACS Catal. 2016, 6, 4559-4563. [CrossRef]

51. Rünzi, T.; Tritschler, U.; Roesle, P.; Göttker-Schnetmann, I.; Möller, H.M.; Caporaso, L.; Poater, A.; Cavallo, L.; Mecking, S. Activation and Deactivation of Neutral Palladium(II) Phosphinesulfonato Polymerization Catalysts. Organometallics 2012, 31, 8388-8406. [CrossRef]

52. Das, R.K.; Saha, B.; Rahaman, S.M.W.; Bera, J.K. Bimetallic Catalysis Involving Dipalladium(I) and Diruthenium(I) Complexes. Chem. Eur. J. 2010, 16, 14459-14468. [CrossRef]

53. Aufiero, M.; Proutiere, F.; Schoenebeck, F. Redox Reactions in Palladium Catalysis: On the Accelerating and/or Inhibiting Effects of Copper and Silver Salt Additives in Cross-Coupling Chemistry Involving Electron-rich Phosphine Ligands. Angew. Chem. Int. Ed. 2012, 51, 7226-7230. [CrossRef]

54. Proutiere, F.; Aufiero, M.; Schoenebeck, F. Reactivity and Stability of Dinuclear Pd(I) Complexes: Studies on the Active Catalytic Species, Insights into Precatalyst Activation and Deactivation, and Application in Highly Selective Cross-Coupling Reactions. J. Am. Chem. Soc. 2011, 134, 606-612. [CrossRef]

55. Hansmann, M.M.; Pernpointner, M.; Döpp, R.; Hashmi, A.S.K. A Theoretical DFT-Based and Experimental Study of the Transmetalation Step in Au/Pd-Mediated Cross-Coupling Reactions. Chem. Eur. J. 2013, 19, 15290-15303. [CrossRef]

56. Naumann, S.; Scholten, P.B.V.; Wilson, J.A.; Dove, A.P. Dual Catalysis for Selective Ring-Opening Polymerization of Lactones: Evolution toward Simplicity. J. Am. Chem. Soc. 2015, 137, 14439-14445. [CrossRef] [PubMed]

57. Xu, T.; Chen, E.Y.-X. Silylium dual catalysis in living polymerization of methacrylates via In situ hydrosilylation of monomer. J. Polym. Sci. Part A Polym. Chem. 2015, 53, 1895-1903. [CrossRef]

58. Sammis, M.G.; Danjo, H.; Jacobsen, N.E. Cooperative Dual Catalysis: Application to the Highly Enantioselective Conjugate Cyanation of Unsaturated Imides. J. Am. Chem. Soc. 2004, 126, 9928-9929. [CrossRef]

59. Rueping, M.; Antonchick, A.P.; Brinkmann, C. Dual catalysis: A combined enantioselective brønsted acid and metal-catalyzed reaction-Metal catalysis with chiral counterions. Angew. Chem. Int. Ed. 2007, 46, 6903-6906. [CrossRef]

60. Du, J.; Skubi, K.L.; Schultz, D.M.; Yoon, T.P. A Dual-Catalysis Approach to Enantioselective [2+2] Photocycloadditions Using Visible Light. Science 2014, 334, 392-396. [CrossRef]

61. Peters, R. Cooperative Catalysis: Designing Efficient Catalysis for Synthesis; John Wiley and Sons: Hoboken, NJ, USA, $2015 ;$ p. 16.

62. Corey, E.J.; Bakshi, R.K.; Shibata, S. Highly enantioselective borane reduction of ketones catalyzed by chiral oxazaborolidines. Mechanism and synthetic implications. J. Am. Chem. Soc. 1987, 109, 5551-5553. [CrossRef]

63. DiMauro, E.F.; Kozlowski, M.C. Salen-Derived Catalysts Containing Secondary Basic Groups in the Addition of Diethylzinc to Aldehydes. Org. Lett. 2001, 3, 3053-3056. [CrossRef]

64. DiMauro, E.F.; Kozlowski, M.S. The First Catalytic Asymmetric Addition of Dialkylzincs to $\alpha$-Ketoesters. Org. Lett. 2002, 4, 3781-3784. [CrossRef]

65. Wadamoto, M.; Ozasa, N.; Yanagisawa, A.; Yamamoto, H. BIN-AP/AgOTf/KF/18-Crown-6 as New Bifunctional Catalysts for Asymmetric Sakurai-Hosomi Allylation and Mukaiyama Aldol Reaction. J. Org. Chem. 2003, 68, 5593-5601. [CrossRef] [PubMed]

66. Denmark, S.E.; Chung, W.-J. Lewis Base Activation of Lewis Acids: Catalytic, Enantioselective Addition of Glycolate-Derived Silyl Ketene Acetals to Aldehydes. J. Org. Chem. 2008, 73, 4582-4595. [CrossRef]

67. Kobayashi, S.; Hamada, T.; Manabe, K. The Catalytic Asymmetric Mannich-Type Reactions in Aqueous Media. J. Am. Chem. Soc. 2002, 124, 5640-5641. [CrossRef]

68. Ohkuma, T.; Ooka, H.; Hashiguchi, S.; Ikariya, T.; Noyori, R. Practical Enantioselective Hydrogenation of Aromatic Ketones. J. Am. Chem. Soc. 1995, 117, 2675-2676. [CrossRef]

69. Mikhailine, A.A.; Maishan, M.I.; Lough, A.J.; Morris, R.H. The Mechanism of Efficient Asymmetric Transfer Hydrogenation of Acetophenone Using an Iron(II) Complex Containing an (S,S)- $\mathrm{Ph}_{2} \mathrm{PCH}_{2} \mathrm{CH}=\mathrm{NCHPhCHPhN}=\mathrm{CHCH} 2 \mathrm{PPh} 2 \mathrm{Ligand}_{2} \mathrm{Partial}$ Ligand Reduction Is the Key. J. Am. Chem. Soc. 2012, 134, 12266-12280. [CrossRef]

70. Zuo, W.; Lough, A.J.; Li, Y.F.; Morris, R.H. Amine(imine)diphosphine Iron Catalysts for Asymmetric Transfer Hydrogenation of Ketones and Imines. Science 2013, 342, 1080-1083. [CrossRef] [PubMed]

71. Westerhausen, D.; Herrmann, S.; Hummel, W.; Steckhan, E. Formate-Driven, Non-Enzymatic NAD(P)H Regeneration for the Alcohol Dehydrogenase Catalyzed Stereoselective Reduction of 4-Phenyl-2-butanone. Angew. Chem. Int. Ed. 1992, 31, 1529-1531. [CrossRef]

72. Allen, J.V.; Williams, J.M.J. Dynamic kinetic resolution with enzyme and palladium combinations. Tetrahedron Lett. 1996, 37, 1859-1862. [CrossRef]

73. Dinh, P.M.; Howarth, J.A.; Hudnott, A.R.; Williams, J.M.J.; Harris, W. Catalytic racemisation of alcohols: Applications to enzymatic resolution reactions. Tetrahedron Lett. 1996, 37, 7623-7626. [CrossRef]

74. Pàmies, O.; Bäckvall, J.-E. Combination of Enzymes and Metal Catalysts. A Powerful Approach in Asymmetric Catalysis. Chem. Rev. 2003, 103, 3247-3261. [CrossRef] 
75. Denard, C.A.; Huang, H.; Bartlett, M.J.; Lu, L.; Tan, Y.; Zhao, H.; Hartwig, J.F. Cooperative Tandem Catalysis by an Organometallic Complex and a Metalloenzyme. Angew. Chem. Int. Ed. 2013, 126, 465-469. [CrossRef]

76. Simons, C.; Hanefeld, U.; Arends, I.W.C.E.; Maschmeyer, T.; Sheldon, R.A. Towards catalytic cascade reactions: Asymmetric synthesis using combined chemo-enzymatic catalysts. Top. Catal. 2006, 40, 35-44. [CrossRef]

77. Abdellah, I.; Poater, A.; Lohier, J.-F.; Gaumont, A.-C. Au(I)-Catalyzed Hydroarylation of Alkenes with N,N-dialkylanilines: A Dual Gold Catalysis Concept. Catal. Sci. Technol. 2018, 8, 6486-6492. [CrossRef]

78. Burns, N.Z.; Witten, M.R.; Jacobsen, E.N. Dual Catalysis in Enantioselective Ox-idopyrylium-Based [5 + 2] Cycloadditions. J. Am. Chem. Soc. 2011, 133, 14578-14581. [CrossRef]

79. Oliveira, M.T.; Luparia, M.; Audisio, D.; Maulide, N. Dual Catalysis Becomes Diastereodivergent. Angew. Chem. Int. Ed. 2013, 52, 13149-13152. [CrossRef] [PubMed]

80. Hanna, L.E.; Jarvo, E.R. Selective Cross-Electrophile Coupling by Dual Catalysis. Angew. Chem. Int. Ed. 2015, 54, 15618-15620. [CrossRef]

81. Cheong, P.H.Y.; Morganelli, P.; Luzung, M.R.; Houk, K.N.; Toste, F.D. Gold-Catalyzed Cycloisomerization of 1,5-Allenynes via Dual Activation of an Ene Reaction. J. Am. Chem. Soc. 2008, 130, 4517-4526. [CrossRef]

82. Gaillard, S.; Bosson, J.; Ramon, R.S.; Nun, P.; Slawin, A.M.Z.; Nolan, S.P. Development of Versatile and Silver-Free Protocols for Gold(I) Catalysis. Chem. Eur. J. 2010, 16, 13729-13740. [CrossRef]

83. Brown, T.J.; Widenhoefer, R.A. Cationic Gold(I) $\pi$-Complexes of Terminal Alkynes and Their Conversion to Dinuclear $\sigma, \pi-$ Acetylide Complexes. Organometallics 2011, 30, 6003-6009. [CrossRef]

84. Roithová, J.; Janková, Š.; Jašíková, L.; Váňa, J.; Hybelbauerová, S. Gold-Gold Cooperation in the Addition of Methanol to Alkynes. Angew. Chem. Int. Ed. 2012, 51, 8378-8382. [CrossRef]

85. Jašíková, L.; Anania, M.; Hybelbauerová, S.; Roithová, J. Reaction Intermediates Kinetics in Solution Investigated by Electrospray Ionization Mass Spectrometry: Diaurated Complexes. J. Am. Chem. Soc. 2015, 137, 13647-13657. [CrossRef]

86. Anania, M.; Jašíková, L.; Jašík, J.; Roithová, J. Why can a gold salt react as a base? Org. Biomol. Chem. 2017, 15, 7841-7852. [CrossRef]

87. Anania, M.; Jašíková, L.; Zelenka, J.; Shcherbachenko, E.; Jašík, J.; Roithová, J. Monoaurated vs. diaurated intermediates: Causality or independence? Chem. Sci. 2020, 11, 980-988. [CrossRef]

88. Larsen, M.H.; Houk, K.N.; Hashmi, A.S.K. Dual Gold Catalysis: Stepwise Catalyst Transfer via Dinuclear Clusters. J. Am. Chem. Soc. 2015, 137, 10668-10676. [CrossRef] [PubMed]

89. Oonishi, Y.; Gómez-Suárez, A.; Martin, A.R.; Nolan, S. Hydrophenoxylation of Alkynes by Cooperative Gold Catalysis. Angew. Chem. Int. Ed. 2013, 52, 9767-9771. [CrossRef] [PubMed]

90. Dupuy, S.; Gasperini, D.; Nolan, S.P. Highly Efficient Gold(I)-Catalyzed Regio- and Stereoselective Hydrocarboxylation of Internal Alkynes. ACS Catal. 2015, 5, 6918-6921. [CrossRef]

91. Gómez-Suárez, A.; Oonishi, Y.; Martin, A.R.; Vummaleti, S.V.C.; Nelson, D.; Cordes, D.; Slawin, A.M.Z.; Cavallo, L.; Nolan, S.P.; Poater, A. On the Mechanism of the Digold(I)-Hydroxide-Catalysed Hydrophenoxylation of Alkynes. Chem. Eur. J. 2016, 22, 1125-1132. [CrossRef] [PubMed]

92. Cavarzan, A.; Scarso, A.; Sgarbossa, P.; Strukul, G.; Reek, J.N.H. Supramolecular Control on Chemo- and Regioselectivity via Encapsulation of (NHC)-Au Catalyst within a Hexameric Self-Assembled Host. J. Am. Chem. Soc. 2011, 133, 2848-2851. [CrossRef]

93. Jans, A.C.H.; Gómez-Suárez, A.; Nolan, S.P.; Reek, J.N.H. A Switchable Gold Catalyst by Encapsulation in a Self-Assembled Cage. Chem. Eur. J. 2016, 22, 14836-14839. [CrossRef]

94. Escayola, S.; Poater, J.; Ramos, M.; Luque-Urrutia, J.A.; Duran, J.; Simon, S.; Solà, M.; Cavallo, L.; Nolan, S.P.; Poater, A. Chelation enforcing a dual gold configuration in the catalytic hydroxyphenoxylation of alkynes. Appl. Organomet. Chem. 2021. unpublish.

95. Lazreg, F.; Guidone, S.; Gómez-Herrera, A.; Nahra, F.; Cazin, C.S.J. Hydrophenoxylation of internal alkynes catalysed with a heterobimetallic Cu-NHC/Au-NHC system. Dalton Trans. 2017, 46, 2439-2444. [CrossRef]

96. Gonzalez-Belman, O.F.; Jiménez-Halla, J.O.C.; Nahra, F.; Cazin, C.S.J.; Poater, A. The role of the metal in the dual-metal catalysed hydrophenoxylation of diphenylacetylene. Catal. Sci. Technol. 2018, 8, 3638-3648. [CrossRef]

97. Ramos, M.; Poater, J.; Villegas-Escobar, N.; Gimferrer, M.; Toro-Labbé, A.; Cavallo, L.; Poater, A. Phenoxylation of Alkynes through Mono- and Dual Activation Using Group 11 (Cu, Ag, Au) Catalysts. Eur. J. Inorg. Chem. 2020, 2020, 1123-1134. [CrossRef]

98. D’Elia, V.; Ghani, A.A.; Monassier, A.; Sofack-Kreutzer, J.; Pelletier, J.D.A.; Drees, M.; Vummaleti, S.V.C.; Poater, A.; Cavallo, L.; Cokoja, M.; et al. Dynamics of the $\mathrm{NbCl}_{5}$-catalyzed cycloaddition of propylene oxide and $\mathrm{CO}_{2}$ : Assessing the dual role of the nucleophilic Co-catalysts. Chem. Eur. J. 2014, 20, 11870-11882. [CrossRef]

99. D'Elia, V.; Dong, H.; Rossini, A.; Widdifield, C.; Vummaleti, S.V.C.; Minenkov, Y.; Poater, A.; Abou-Hamad, E.; Pelletier, J.D.A.; Cavallo, L.; et al. Cooperative effect by monopodal surface niobium complexes enhancing cyclic carbonate production. J. Am. Chem. Soc. 2015, 137, 7728-7739. [CrossRef]

100. Arayachukiat, S.; Yingcharoen, P.; Vummaleti, S.V.; Cavallo, L.; Poater, A.; D’Elia, V. Cycloaddition of $\mathrm{CO}_{2}$ to challenging N-tosyl aziridines using a halogen-free niobium complex: Catalytic activity and mechanistic insights. Mol. Catal. 2017, 443, 280-285. [CrossRef]

101. Gimferrer, M.; D’Alterio, M.C.; Talarico, G.; Minami, Y.; Hiyama, T.; Poater, A. Allyl Monitorization of the Regioselective Pd-Catalyzed Annulation of Alkylnyl Aryl Ethers Leading to Bismethylenechromanes. J. Org. Chem. 2020, 85, 12262-12269. [CrossRef] 